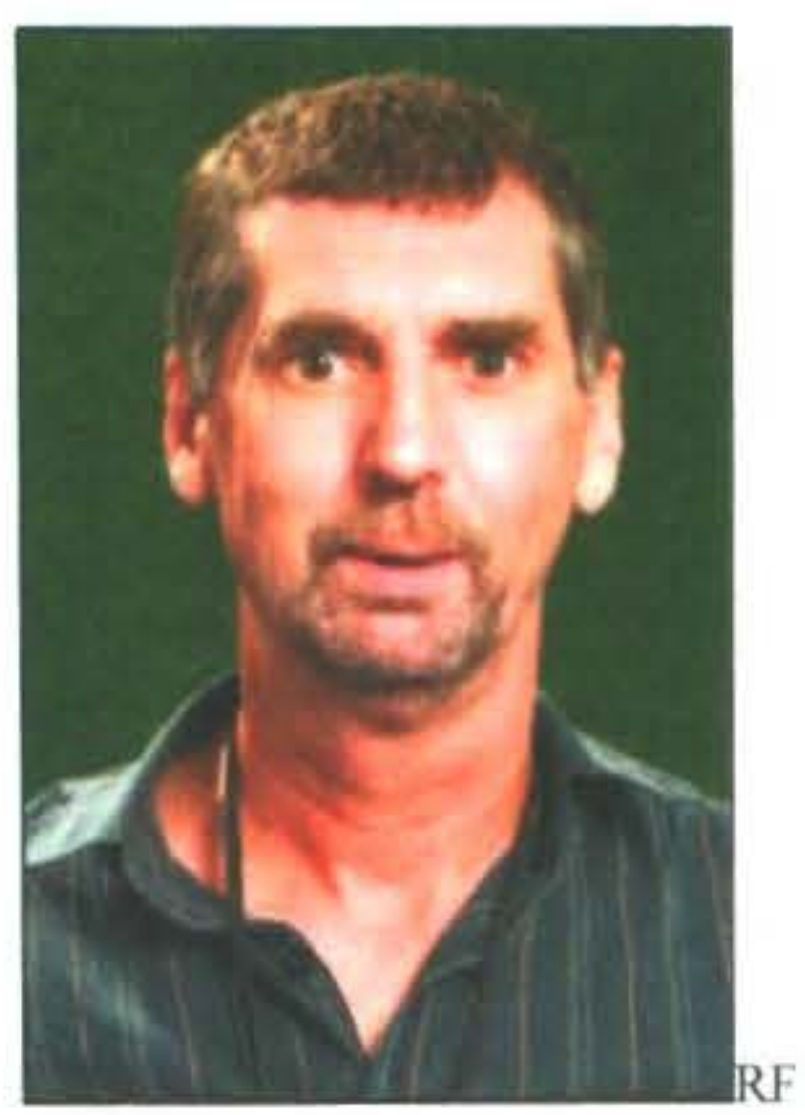

\section{THE EFFECTS OF \\ ORGANISATIONAL \\ SOCIALISATION ON INDIVIDUAL \\ AND ORGANISATIONAL \\ OUTCOMES: A REVIEW \\ OF THE LITERATURE AND \\ DIRECTIONS FOR FUTURE \\ RESEARCH}

Robbie Field

School of Business

Eastern Institute of Technology

\author{
Alan Coetzer \\ Department of Management \\ College of Business \\ Massey University, Wellington Campus
}

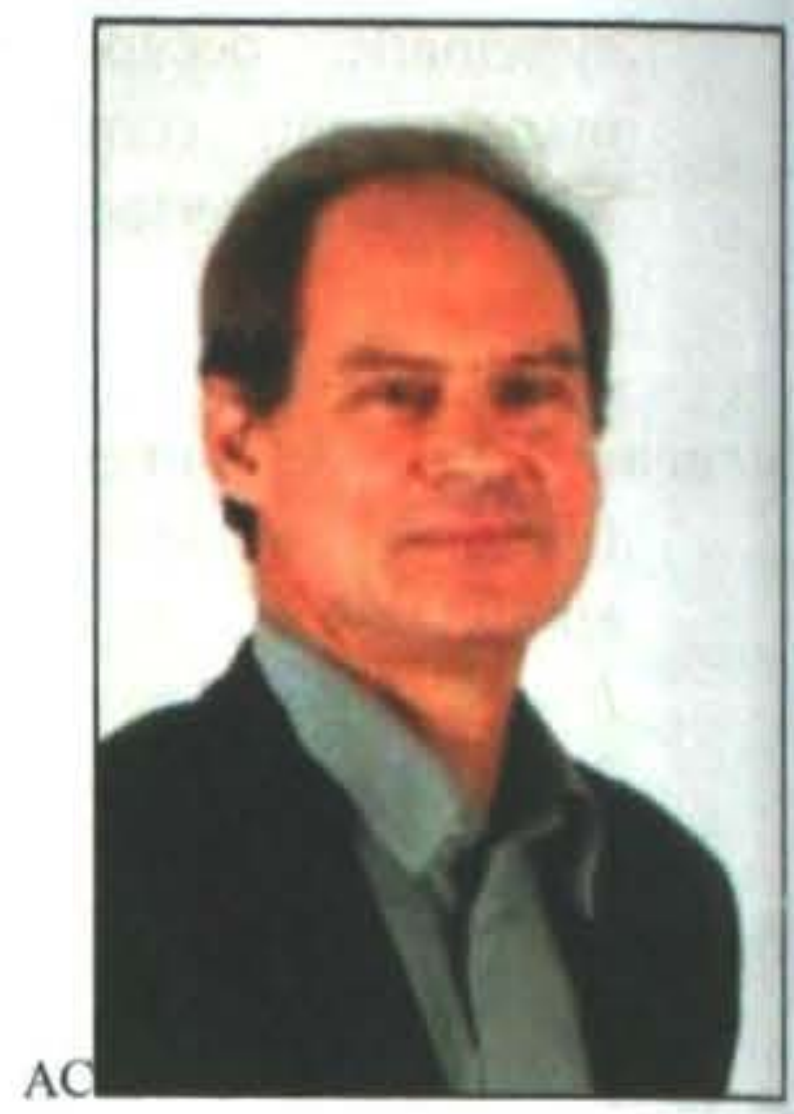

\begin{abstract}
Organisational socialisation (OS) is a critical process that all employees experience and the efficiency and effectiveness of the OS process impacts on the individual's ability to adjust and perform, as well as the organisation's capacity to obtain employee commitment and retain staff. The purpose of this paper is to provide a review of the OS literature that examines the links between the OS process and important individual and organisational outcomes, in order to identify opportunities for further empirical research in this area. From a review of the literature undertaken, it was found that despite the strong arguments supporting the significance of OS and its links to important individual and organisational outcomes, important knowledge 'gaps' exist in the OS literature. These include knowledge on the relationship between pre-encounter and encounter socialisation, the role of individual differences in newcomer adjustment, and the differences in OS approaches between small and large firms. The review of the literature also found significant methodological weaknesses in the literature. For instance, little research has examined OS from an employer and employee perspective. The paper concludes with suggestions for further research in order to stimulate study into particular aspects of $O S$.
\end{abstract}

\section{Introduction}

New employment represents challenges for both the new employee and the organisation. The newcomer faces novel work and organisational situations that requires new knowledge and skills to adjust to these unfamiliar circumstances, whilst for the organisation the uncertainty newcomers experience increases the likelihood of labour mobility that impacts on retention (Filstad, 2004). This process of newcomer adjustment to their new work and organisational context, through learning the required knowledge, skills and attitudes to function as fully effective and integrated members of the organisation, is referred to as organisational socialisation (OS) (e.g. Fisher, 1986; Van Maanen, 1978).

The challenges of new employment for newcomers and organisations, together with the need to socialise newcomers as quickly and effectively as possible, are especially important when viewed against the background of changes in a competitive business environment. A combination of factors such as business process re-engineering, mergers, acquisitions outsourcing, downsizing and increasing usage of contingent workers is affecting the world of work and the nature of the employment relationship between employer and employee (Du Plessis, Beaver \& Nel, 2006; Millward \& Brewerton, 2000).

Research undertaken into OS suggests that it is an important human resource management (HRM) practice, which can lead to successful individual and organisational outcomes (Cooper-Thomas and Anderson, 2006). Several researchers have found that the indicators of OS success are reflected in desirable outcomes and the reduction in negative outcomes for both the newcomer and organisation (e.g., Bauer, Bodner, Erdogen, Truxillo \& Tucker, 2007; Feldman, 1981; Saks \& Ashforth, 1997; 
Saks, Uggerslev \& Fassina, 2006; Van Maanen \& Schein, 1979). Organisational socialisation process variables that include role clarity, task mastery, social integration and organisational commitment are shown to consistently affect key organisational outcomes such as an organisation's ability to retain staff and employee performance (Cooper-Thomas \& Anderson, 2002; Fisher, 1986; Mitchell, Holtom, Lee, Sabblynski, \& Erez, 2001; Saks \& Ashforth, 1997; Slattery, Selvarajan \& Anderson, 2002).

The purpose of this paper is to provide a review of the OS literature that examines the links between the OS process and important individual and organisational outcomes, in order to identify opportunities for further empirical research in this area. The OS literature reviewed focuses on the nature and significance of OS, as well as the OS process and related outcomes. The roles of newcomers and socialisation agents in OS are also briefly reviewed. This paper also examines the small body of literature on OS in the context of small firms. The article concludes with suggestions for further research into certain aspects of OS.

\section{Literature Review}

\section{Nature of Organisational Socialisation}

Defining OS has progressed from a general description of "learning the ropes" (Schein, 1968; Van Maanen, 1978), to being defined as a learning process through which newcomers make the transition from organisational 'outsider' to effective participating and contributing 'insider', while adjusting to their roles in the context of their new workplace environment (Bauer, et al., 2007; Cooper-Thomas \& Anderson, 2006; Feldman, 1976; Feldman, 1981). Although definitions of OS have developed over time, current conceptualisations and research (e.g. Cooper-Thomas \& Anderson, 2006; Saks \& Ashforth, 1997; Saks, et., 2006) continues to focus on the two key 'traditional' aspects of OS, namely: (1) that it is a learning process; and (2) it concerns newcomer adjustment to their environments (e.g. Feldman, 1976; Jones; 1983; Jones; 1986; Louis; 1980; Van Maanen \& Schein, 1979). OS is ubiquitous, occurring each and every time an employee crosses an external boundary (e.g. between two organisations) or an internal boundary (e.g. a departmental transfer within an organisation) (Van Maanen \& Schein, 1979). Whenever this occurs, functionally, the individual is considered a 'newcomer', with ongoing learning crucial to successful adjustment of the new employee to the work environment (Van Maanen, 1978).

\section{Significance of Organisational Socialisation for Newcomers}

The importance of OS from a newcomer perspective needs to be viewed against the background of the expectations, uncertainty and stress that exists when an employee joins an organisation and the reality encountered when adjusting to new employment. Newcomers face work situations not previously experienced, they encounter values and norms they are unfamiliar with, are expected to fit in with new work colleagues and learn the ropes. New employees are required to acquire and develop attitudes and behaviours necessary to function as fully-fledged members of an organisation (Ardts, Jansen \& Van der Velde, 2001). For the newcomer, the resultant indicators of successful socialisation include reduced stress and anxiety, better functioning in a new role, the increased ability to perform certain tasks and integration into a new working environment (Bauer, et al., 2007; Feldman, 1981; Saks \& Ashforth, 1997; Saks, et al., 2006; Van Maanen \& Schein, 1979). These OS success indicators are also important for the organisation in achieving certain OS outcomes.

\section{Significance of Organisational Socialisation for the Organisation}

The speedy and effective adjustment of the newcomer to new tasks, roles and organisational values and norms is of particular significance to the organisation because of the positive effects these variables have on the critical OS outcome of performance, as well as productivity and staff retention (i.e. turnover). Filstad (2004, p.403) emphasises the significance of OS by stating that:

The focus on organisational socialisation and how new employment is a continuing challenge for the newcomer, organisations and society is important, and is a reminder of the consequences if we do not take these learning processes seriously.

For the organisation, low turnover is frequently identified as being the most critical OS outcome (Cooper-Thomas $\&$ Anderson, 2006). The cost implications of turnover are of primary concern for most organisations (Foote, 2004). Newcomers who are a net drain on productivity and incur costs as they go through a learning curve, whilst providing little in return, are a luxury that can be ill afforded and firms need to retain newcomers for sufficient time to at least warrant the outlay incurred (Rollag, Praise \& Cross, 2005). Cooper-Thomas and Anderson (2006) emphasise the high direct costs (separation, replacement, training and general administration support costs) and indirect costs (lower productivity, reduced customer loyalty) related to the inability of organisations to retain staff. Turnover occurring soon after entering the organisation is especially costly (Dess \& Shaw, 2001), as organisations have not yet obtained a return on investment on initial outlay in

recruitment and selection, training and development, and remuneration, and replacement costs are high (Kammeyer-Mueller \& Wanberg, 2003; Wanous, 1980). 
These substantial direct and indirect costs and the time organisations invest socialising new employees is an incentive to ensure that the OS processes are as effective and efficient as can be (Louis, Posner \& Powell, 1983).

As previously noted, various commentators recognise the significance of OS for employees and organisations (e.g. Cooper-Thomas \& Anderson, 2006; Saks, et al., 2006) and there has been a marked increase in attention to the topic of OS (Ardts, et al., 2001).

Despite the significance of OS being recognised by various commentators, organisations are not always aware of the OS process and actual socialisation experiences newcomers are exposed to in their attempts to adjust to their environment (Cable \& Parsons, 2001). Many organisations and employees weather the OS experience unconsciously, going through the process 'blindly', unaware of its powerful influences and numerous long lasting effects (Kweisga \& Bell. 2004).

\section{The Organisational Socialisation Process}

The socialisation process, where the new employee adapts from 'outsider' to 'insider", commences prior to the employee joining the organisation (pre-employment), resumes when the newcomer starts employment and continues with further adjustments and changes taking place until the newcomer becomes a fully integrated member of the organisation (Ardts, et al., 2001). The majority of theorists and researchers view OS as a multistage process consisting of three main phases (stages), with a range of activities and resultant outcomes (Fisher, 1986; Haski-Leventhal \& Bargal, 2008). These phases are: an anticipatory phase that occurs prior to organisational entry (pre-encounter): an accommodation (encounter) phase, when the newcomer enters the organisation, observes and experiences what the organisation is really like and where expectations and reality are tested; and lastly, an adaptation phase during which the newcomer adapts, settles in and relatively long-lasting change occurs (e.g. Allen, 2006; Ardts, et al., 2001: Bauer, et al., 1998; Feldman, 1976; Feldman, 1981: Filstad, 2004; Louis, 1980; Schein, 1978: Van Maanen; 1976). Griffeth, Allen and Barrett (2006) designated these stages "getting in", "breaking in" and "settling in" respectively. Phase models outlining the OS process provide a systematic, theoretical framework to conduct further empirical research in the area of socialisation (Feldman, 1981).

\section{Pre-encounter and Encounter Phases of the Organisational Socialisation Process}

The pre-encounter and encounter phases of the OS process are critical in determining newcomer adjustment, establishing the long lasting relationship between employee and employer and in achieving OS outcomes (Ashford \& Black, 1996; Buckley, Fedor, Veres, Wiese \& Carraher, 1998; Cooper-Thomas, Van Vianen \&
Anderson, 2004; Filstad, 2004; Kammeyer-Mueller \& Wanberg, 2003, Kickul, 2001). Most newcomer socialisation takes place during the early period before (pre-encounter) and following organisational entry (encounter) (e.g. Filstad, 2004; Kammeyer-Mueller \& Wanberg, 2003; Kickul, 2001); with the first four months of the OS process having a marked and rapid effect on newcomer adjustment (Ashforth \& Saks, 1996, Cooper-Thomas \& Anderson, 2002). The transition period prior to and just after crossing an organisational boundary, such as the outsider-to-insider passage that occurs during the pre-encounter and encounter phases of socialisation, is critical, as adjustment is at its most intense and problematic for newcomers (Van Maanen \& Schein, 1979). This is because the gap between newcomer perceptions of the organisation formed prior to entry and the actual reality experienced soon after joining the organisation is probably at its widest during this period (Fisher, 1986; Nicholson \& Arnold, 1991).

During the pre-encounter phase important information is provided to the newcomer about the organisation and the job that is crucial to newcomer adjustment (KammeyerMueller \& Wanberg, 2003). The socialisation of newcomers that commences before newcomers enter the organisation is a result of expectations created during recruitment and selection, interactions with organisational members and preconceptions formed about the organisation through other sources (e.g. friends and media) prior to joining (Rollag, 2004). These experiences from different sources and situations prior to joining an organisation influence newcomer behaviours when they encounter the new organisation (Bandura, 1977; Fisher, 1986). Despite the importance of expectations and experiences that influence newcomer adjustment prior to organisational entry; research over the last 20 plus years has paid little attention to and does not clarify the role of pre-entry variables in newcomer adjustment (Jones, 1983; Kammeyer-Mueller, 2003).

Most organisational socialisation theorists and researchers agree that the encounter phase of OS is a key moment for the newcomer (Barge \& Schlueter, 2004; Kammeyer-Mueller \& Wanberg, 2003). Because of the unfamiliarity and uncertainty that exists when newcomers are exposed to their new environments, the early experiences of newcomers as they enter the organisation plays a particularly important role in the adjustment of the newcomer to the organisation (De Vos, Buyens \& Schalk, 2003). In addition, studies show that recently recruited employees are the most likely to exit the organisation if early entry experiences do not assist newcomers in learning to adjust to their new environment (Allen, 2006). The encounter phase of newcomer adjustment occurs during the weeks and months following entry into the organisation (Morrison, 1995) when newcomers become aware of the organisational context as they begin to explore their role in the organisation and start recognising and evaluating 
the gaps between their expectations and the reality they experience (Jones, 1993).

Research shows that newcomer attitudes and behaviours after entry are highly correlated with those many months later and the degree of newcomer adjustment during later stages of the socialisation process (e.g. Cooper-Thomas, et al., 2004; Morrison, 1993; Saks \& Ashforth, 1997; Wanous, 1992). The more rigorous and intensive the socialisation practices are pre-entry and post-entry; the more congruent are the newcomer attitudes and behaviours with that of the organisation (Chatman, 1991). According to Reichers (1987), the encounter phase ends when newcomer anxiety is reduced and the meanings newcomers and insiders attach to organisational life is similar.

\section{Organisational Socialisation Tactics and Newcomer Adjustment}

One of the most widely used approaches to understanding OS is Van Maanen and Schein's (1979) theoretical model of socialisation, which provides a typology of socialisation tactics that organisations use to structure the early work experiences of newcomers (Ashforth \& Saks, 1996). According to the model, organisations use a variety of tactics to socialise newcomers that are classified into six dimensions that exist on a bipolar continuum (Van Maanen \& Schein, 1979). These tactics are: (1) Formal versus Informal tactics that refer to newcomers going through a structured process segregated from other employees, as opposed to little or no segregation between newcomers and other employees; (2) Individual versus Collective tactics concerning approaches to newcomers being socialised as part of a group or individually, separate from other newcomers; (3)

Fixed versus Variable practices referring to newcomers proceeding through the socialisation process according to a fixed schedule, which has been communicated or having no specific schedule; (4) Sequential versus Random approaches that entails newcomers being aware of a planned OS process or being uncertain as to how the process will progress; (5) Investiture versus Divestiture, which affirms newcomer identity, or the lack of identity affirmation/attempt to change newcomer identity, through feedback and support from insiders; and (6) a Serial versus Disjunctive process that refers to newcomers being socialised with the assistance of previous job incumbents as role models or the lack of/absence of role models. These socialisation tactics are viewed as general characteristics of actual actions or approaches taken by organisations to facilitate newcomer adjustment (Ardts, et al., 2001; Barge \& Schluter, 2004; Bauer et al., 2007). For example, a structured socialisation programme introduced as part of an OS process to socialise a group of recently recruited engineering graduates employed by a large organisation, could include a combination of formal, collective, fixed, sequential, investiture and serial tactics.

Building on Van Maanen and Schein's (1979) conceptual model of OS, Jones (1986) conducted the first empirical study on the relationship between socialisation tactics and newcomer adjustment. This research by Jones (1986) examines socialisation tactics in relation to two main categories, namely institutionalised (formal, collective, fixed, sequential, investiture and serial) or individualised (informal, individual, variable, random, divestiture and disjunctive). The socialisation tactics are categorised into an additional three factor framework. namely context (collective-individual and formalinformal), content (sequential-random and fixedvariable) and social aspects (serial-disjunctive and investiture-divestiture).

The classification of Jones' (1986) six tactical dimensions into the different categories is shown in Figure 1.

Figure 1: A Classification of Socialisation Tactics

\begin{tabular}{lll}
\hline $\begin{array}{l}\text { Tactics concerned } \\
\text { mainly with: }\end{array}$ & INSTITUTIONALISED & INDIVIDUALISED \\
\hline CONTEXT & Collective & Individual \\
& Formal & Informal \\
CONTENT & Sequential & Random \\
& Fixed & Variable \\
SOCIAL ASPECTS & Serial & Disjunctive \\
& Investiture & Divestiture \\
\hline
\end{tabular}

According to Jones (1986), institutionalised tactics reduce uncertainty experienced during early entry into the organisation and the organisation attempts to reinforce the organisational status quo, with newcomers being largely passive participants in the OS process. On the other hand, an individualised approach represents less organisational involvement and structure in socialisation, which result in newcomers being more active participants in their own socialisation. This can result in increased uncertainty. Research examining the 
relationship between Jones' classification of tactics and resultant outcomes, is consistent with the basic proposition that different socialisation approaches affect newcomer adjustment in different ways (Saks, et al., 2006).

The majority of OS research continues to focus on socialisation tactics or proactive newcomer behaviour (Ardts, et al., 2001), with more than 30 studies on socialisation tactics being undertaken during the last 20 years (Saks, et al., 2006). Notwithstanding the fairly extensive research covering socialisation tactics, the different socialisation tactics remains to some extent a "black box", insofar as determining the actual activities associated with specific tactics is concerned (Ashforth, Sluss \& Saks, 2007). Furthermore, the importance literature attaches to certain tactics, such as collective and formal, may be attributed to the use of highly unusual or extreme settings, such as military socialisation programmes to illustrate points (Jones, 1986). Results of a recent meta-analysis on the

relationship between socialisation tactics and newcomer adjustment undertaken by Saks, et al. (2006) indicate that organisations should take a "contingency approach" to socialisation practices. For example, organisations need not choose between an individualised or institutionalised approach, but if required can use a combination of both.

\section{Role of Newcomers in Organisational Socialisation}

The term 'newcomer' in relation to OS is an employee status attached to entry into a firm (Rollag, 2004). This implies a specific employee grouping separate from other employees in an organisation (Jackson, Stone \& Alvarez, 1992). Socialisation literature tacitly portrays newcomers as passive participants in their own adjustment, subject to the influence of organisational efforts to socialise them (Ashforth, et al., 2007). This view is supported by most socialisation research that regards the organisation as the primary controller of the socialisation process and the role of newcomer individual differences in the socialisation process is rarely considered (Reichers, 1987). Newcomers play an active role in their own socialisation, with individual differences affecting their adjustment (Seibert, Crant \& Kraimer, 2000; Jones, 1983).

Examples of the individual characteristics that influence newcomer adjustment include personality (Ashforth \& Saks, 1996; Wanberg \& Kammeyer-Mueller, 2000), demographic characteristics (e.g. age, education, experience) (Kirchmeyer, 1995); proactive behaviour (Seibert, Crant \& Kraimer, 2000; Ashforth, et al., 2007), and self efficacy (Jones, 1986; Major \& Kozlowski, 1997; Saks, 1994). Collecting data on individual differences prior to organisational entry (e.g. during recruitment and selection), assists in determining the influence individual differences has on newcomer adjustment and resultant OS outcomes (Cooper-Thomas \& Anderson, 2006; Jones 1983). During entry to the organisation, these individual differences also influence the newcomer's initial psychological orientation towards the organisation and the way in which they experience organisational reality (Ashford \& Black, 1996; Jones, 1983).

\section{Role of Socialisation Agents in Organisational Socialisation}

Although newcomers play an active role in their own socialisation and sense making by seeking information and feedback (Cooper-Thomas \& Anderson, 2002; Feldman, 1981; Morrison, 1993), a large part of newcomer knowledge about the organisation and the job is determined by the amount and accuracy of information obtained from the employing organisation's sources (Carr, Pearson, Vest \& Boyer, 2006). The important role of insiders, such as supervisors and co-workers, as socialisation agents (Starr \& Fondas, 1992) on newcomer adjustment is confirmed in empirical research and highlighted in the socialisation literature (e.g., Allen, 2006; Cooper-Thomas \& Anderson, 2006; Morrison, 1993; Morrison, 2002; Louis, Posner \& Powell, 1983; Ostroff \& Kozlowski; 1992).

Socialisation agents are those employees inside an organisation who influence the attitudes and behaviours of newcomers (Feldman, 1994). Supervisors and colleagues, as key socialisation agents, are 'insiders' who support newcomer adjustment and help them to "learn the ropes" (Morrison, 1993; Morrison, 2002). These socialisation agents are the most important sources of socialisation information and have the most influence on newcomer adjustment (Beery, 2000). They are also viewed by newcomers as more useful sources of information than formal OS programmes in assisting with newcomer adjustment and achieving positive OS outcomes (Louis, et al., 1983, Cooper-Thomas \& Anderson, 2006).

More specifically, interactions between newcomers and socialisation agents during the early encounter stage of the socialisation process are recognised as the primary vehicle through which socialisation occurs (Reichers, 1987). It is, thus, also important to examine the role of socialisation agents in the socialisation process (Allen, 2006).

\section{An Interactionist Perspective to Organisational Socialisation}

Newcomer adjustment is a process of interaction between both newcomer and organisational insiders (i.e. socialisation agents) influences and it is difficult to predict newcomer adjustment without exploring the nature of socialisation from both an employee and employer perspective (interactionist perspective) (Jones, 
1983; Reichers, 1987). Despite the need for research to examine the OS process from the perspective of both the newcomer and the organisation being recognised since the 1980's (e.g. Jones, 1983; Louis, 1980; Reichers, 1987), most OS research examines the process from the perspective of either the organisation or the newcomer, with the organisation being regarded as the primary influence (Jones, 1983; Louis, 1980). For example, Jones (1986), Saks (1994) and Saks and Ashforth, (1997) include an examination of the influences of newcomer individual differences and actions on newcomer adjustment, whilst other researchers investigate the role of socialisation agents (e.g. Louis, et al., 1983; Morrison, 2002). Reichers (1987) was the first to examine the role of newcomers and organisational insiders simultaneously.

\section{Organisational Socialisation Outcomes}

An OS outcome variable is a criterion by which progress through the OS process is measured and judged (Feldman, 1981). For example, job satisfaction, organisational commitment and intention to quit are consistently viewed by researchers as either adjustment outcomes or indicators of OS success (e.g. CooperThomas \& Anderson, 2002; Mitchell, et al., 2001; Saks \& Ashforth, 1997; Slattery, et al., 2002). Researchers have recently started to differentiate between two categories of outcomes, namely "proximal" (direct) outcomes (e.g. role clarity, which means understanding role requirements), social integration (fitting in with work group) and task mastery (being able to perform the job) (Kammeyer-Mueller \& Wanberg, 2003; Saks \& Ashforth, 1997; Wanberg \& Kammeyer-Mueller, 2000) and "distal" (secondary) outcomes (e.g. job satisfaction, organisational commitment and intention to quit (Bauer, et al., 2007; Saks, et al., 2007). "Proximal" outcomes are direct indicators of newcomer adjustment that occur early in the OS process, whilst "distal" outcomes are influenced by preceding variables, such as "proximal" outcomes of OS (Carr, et al., 2006; Kammeyer-Mueller \& Wanberg, 2003).

As previously noted, turnover is probably the most important OS outcome for the organisation (CooperThomas \& Anderson, 2006), and the relationship between $O S$ and turnover (i.e. retention) is highlighted in various OS studies ( e.g., Allen, 2006; Ashforth, Sluss \& Saks, 2007; Bauer, et al, 2007; Buckley, et al, 1998; Carr, et al., 2006; Cooper-Thomas \& Anderson, 2006; De Vos, et al., 2003; Feldman, 1981).

\section{Differences in Organisational Socialisation Approaches between Small and Large Firms}

Approaches to OS are not associated with any specific type of organisation and in theory apply to any organisational setting (Van Maanen \& Schein, 1979). The majority of OS literature and research assumes that similarities exist in OS processes across different types of organisations and the narrow focus of OS research is on large organisations and certain types of newcomers (e.g. graduate students at universities and employees in the military) (e.g. Ashforth, Saks \& Lee, 1998; CooperThomas \& Anderson, 2002). In practice different approaches to OS are associated with the type of organisational context, which includes organisation size and structure (Ashforth, et al., 1998; Saks, et al., 1998). Organisational size, in particular, is a key contextual variable in the adoption of OS practices (Johns, 1993), with research indicating that OS processes between small and large firms differ (Cardon \& Stevens, 2004).

The OS literature distinguishes between formal and informal approaches to socialisation used by organisations to influence newcomer adjustment and socialisation outcomes (Ardts, et al., 2001; Fisher, 1986; Mutjaba \& Sims, 2001). In small firms most of the OS that takes place is by way of informal activities, whilst socialisation processes in large organisations tend to be more formal (Rollag \& Cardon, 2003). Some commentators have argued that in smaller organisations newcomer socialisation tends to be quicker, inclusive and more extensive, with resultant increased job satisfaction and productivity when compared to larger firms (Cardon, 2001). The greater number of employees in large organisations relative to smaller firms necessitates an institutionalised approach to OS, while an individualised approach to OS is more appropriate for small firms (Ashforth, et al., 1998; Saks, et al., 1998). In addition, certain institutionalised tactics, such as collective, are only feasible in organisations of a certain size (Saks, et al., 1998).

While the influence of organisational contextual factors, such as firm size, on socialisation practices is noted in the literature, little has been done to examine the impact of firm size on the OS processes adopted (Ashforth, et al., 1998, Johns, 1993). The significance of OS in small firms is just as, even if not more important and challenging in achieving desired outcomes, as in large firms (Cardon \& Stevens, 2004; Rollag \& Cardon, 2003). Small firms make a significant contribution to national economies and employment (Massey, 2005) and the ability of small firms to attract and retain staff is central to them remaining competitive (Mayson \& Barret, 2006).

The small body of research into the HRM practice of OS has been conducted in large organisations (e.g., Ashforth, et al., 2007; Cable \& Parsons, 2001; CooperThomas \& Anderson, 2002; Hart, Miller \& Johnson, 2003). Consequently, there is an acute shortage of research in small firms and many questions remain unanswered as to how small firms socialise their employees and ensure they make effective role transitions (Cardon \& Stevens, 2004). 


\section{Future Research}

This review has highlighted a number of knowledge gaps and methodological weaknesses in the existing body of literature on OS. These gaps and weaknesses are outlined in the following paragraphs.

Notwithstanding the importance of the pre-encounter and encounter phases of socialisation for newcomer adjustment being recognised in the literature, little OS research has been conducted in order to establish the relationship between pre-encounter socialisation expectations and encounter experiences (Carr, et al., 2006; Fisher, 1986). Organisations are also not always conscious of the expectations and the way in which actual socialisation practices are experienced by newcomers during these phases of the OS process (Cable \& Parsons, 2001). Future research examining newcomer socialisation information acquisition pre-entry (e.g. during recruitment and selection) and post-entry will improve understanding of the relative importance and relationship of these key phases for newcomer adjustment (Saks, 1994).

Despite recognition in the socialisation literature of the role of individual differences on newcomer adjustment (Kammeyer-Mueller \& Wanberg, 2003), there have been few studies on this (Allen, 2006; Cooper-Thomas \& Anderson, 2006; Jones, 1983; Saks, 1986; Saks, et al., 2007). Further research on the influence of individual differences, such as demographic and personality characteristics, can enhance understanding of the effects of individual differences on newcomer adjustment and OS outcomes.

The critical role of socialisation agents such as supervisors and colleagues ("insiders"), in particular, as important influences on newcomer adjustment is recognised (Beery, 2000; Louis, et al., 1983, CooperThomas \& Anderson, 2006). As previously noted, little is known about the roles of these "insiders" in the OS process and there is a need for studies that obtain data from both newcomers and insiders (Morrison, 2002). By supplementing newcomer assessment of socialisation adjustment variables with those of supervisors and colleagues, future studies have the potential to obtain more valid and useful sources of data (e.g., Ashforth \& Saks, 1996, Ashforth, et al., 2007; Bauer, et al., 1998; Saks \& Ashforth, 1997).

The interactionist perspective has not received a great deal of empirical attention and commentators such as Ashforth, et al. (2007), Griffin, Colella and Goparaju, (2000) and Reichers (1987) highlight the need for research that adopts an interactionist approach towards OS. Thus, further research into the actions and influences of both the organisation and the individual on newcomer adjustment is required.

Given the relationship between OS and individual and organisational outcomes, together with the lack of research of OS in the small firm context and the importance on small firms to national economies and employment, the nature and significance of OS processes in smaller firms requires further research in order to be better understood.

\section{Conclusion}

OS is an important process for both the newcomer and the organisation, with the efficiency and effectiveness of the OS process resulting in successful individual and organisational outcomes. Despite the strong arguments supporting the importance of OS and its links to improving employee and employer outcomes, it is surprising to note that research into this HRM practice and relevant outcomes is neglected. Future research is needed to develop an understanding of the important role of OS and to identify OS practices in use and outcomes. Specific aspects such as the relationship between preencounter and encounter socialisation phases, the role of individual differences in newcomer adjustment, together with an employer and employee perspective are issues that require further attention in OS research. In addition, further studies of OS in the small firm context can fill an important 'gap' in the area of OS research. Research that addresses these specific aspects of OS will provide important information that can contribute towards the development of theory, management practice and SME policy.

\section{References}

Allen, D. G. (2006). Do organizational socialization tactics influence newcomer embeddedness and turnover? Journal of Management, 32, 237-256.

Anonymous. (2001). Supporting an innovative culture in SMEs. Human Resource Management International Digest, 9, 16-18.

Ardts, J., Jansen, P., \& Van der Velde, M. (2001). The breaking in of new employees: Effectiveness of socialization tactics and personnel instruments. Journal of Management Development, 20, 159167.

Ashford, S. J., \& Black, J. S. (1996). Proactivity during organizational entry: The role of desire for control. Journal of Applied Psychology, 81, 199215.

Ashforth, B. E., \& Saks, A. M. (1996). Socialization tactics: Longitudinal effects of newcomer adjustment. Academy of Management Journal, 39, 149-178.

Ashforth, B. E., Saks, A. M., \& Lee, R. T. (1998). Socialization and newcomer adjustment: The role of organizational context. Human Relations, 51, 897-926. 
Ashforth, B. E., Sluss, D. M., \& Saks, A. M. (2007). Socialization tactics, proactive behavior, and newcomer learning: Integrating socialization models. Journal of Vocational Behavior, 70, 447 462.

Bandura, A. (1977). Social learning theory. Englewood Cliffs, NJ: Prentice-Hall.

Barge, K. J., \& Schlueter, D. W. (2004). Memorable messages and newcomer socialization. Western Journal of Communication, 68, 233-256.

Bauer, T. N., Bodner, T., Erdogan, B., Truxillo, D. M., \& Tucker, J. S. (2007). Newcomer adjustment during organizational socialization: A meta-analytic review of antecedents, outcomes, and methods. Journal of Applied Psychology, 92, 707-721.

Bauer, T. N., \& Green, S. G. (1994). Effect of newcomer involvement in work-related activities: A longitudinal study of socialization. Journal of Applied Psychology, 79, 211-223.

Beery, S. A. (2000). Approaches to socializing newcomers and new employee commitment. Unpublished master's thesis, Michigan State University.

Buckly, R. M., Fedor, J. G., Veres, J. G., Wiese, D. S., \& Carraher, S. M. (1998). Investigating newcomer expectations and job-related outcomes. Journal of Applied Psychology, 83, 452-461.

Cable, D. M., \& Parsons, C. K. (2001). Socialization tactics and person-organization fit. Personnel Psychology, 54, 1-23.

Cardon, M. S. (2001). Organizational socialization and knowledge integration of newcomers: The role of anticipated tenure. Unpublished doctorate thesis, Columbia University.

Cardon, M. S., \& Stevens, C. E. (2004). Managing human resources in small organizations: What do we know? Human Resource Management Review, 14, 295-323.

Carr, J. C., Pearson, A. W., Vest, M. J., \& Boyer, S. L. (2006). Prior occupational experience, anticipatory socialization, and employee retention. Journal of Management, 32, 343-359.

Chatman, J. A. (1991). Matching people and organizations: Selection and socialization in public accounting firms. Administrative Science Quarterly, 36, 459-484.

Cooper-Thomas, H. D., \& Anderson, N. (2002). Newcomer adjustment: The relationship between organizational socialization tactics, information acquisition and attitudes. Journal of Occupational and Organizational Psychology, 75, 423-437.

Cooper-Thomas, H. D., \& Anderson, N. (2006). Organisational socialization: A new theoretical model and recommendations for future research and HRM practices in organizations. Journal of Managerial Psychology, 21, 492-516.

Cooper-Thomas, H. D., Van Vianen, A., \& Anderson, N. (2004). Changes in person-organization fit: The impact of socialization tactics on perceived and actual P-O fit. European Journal of Work and Organizational Psychology, 13, 52-78.

Dess, G. D., \& Shaw, J.D. (2001). Voluntary turnover, social capital, and organizational performance. Academy of Management Review, 26, 446-456.

De Vos, A., Buyens. D., \& Schalk, R. (2003). Psychological contract development during organizational socialization: Adaptation to reality and the role of reciprocity. Journal of Organizational Behavior, 24, 537-548.

Du Plessis, A.J., Beaver, B., \& Nel, P. S. (2006). Closing the gap between current capabilities and future requirements in human resource management in New Zealand: Some empirical evidence. Journal of Global Business and Technology, 2, 33-47.

Feldman, D. C. (1976). A practical program for employee socialization. Organizational Dynamics, 64-80.

Feldman, D. C. (1976). A contingency theory of socialization. Administrative Science Quarterly. 21, 433-452.

Feldman, D.C. (1981). The multiple socialization of organizational members. The Academy of Management Review, 6, 309-318.

Feldman, D. C. (1994). Who's socializing whom? The impact of socializing newcomers on insiders, work groups, and organizations. Human Resource Management Review, 4, 213-233.

Filstad, C. (2004). How newcomers use role models in organizational socialization. Journal of Workplace Learning, 16, 396-409.

Fisher, C. D. (1986). Organizational Socialization: An integrative review. Research in Personnel and Human Resources Management, 4, 101-145.

Foote, D. A. (2004). Temporary workers: Managing the problem of unscheduled turnover. Management Decision, 42, 963-973. 
Griffeth, R. W., Hom, P. W., \& Gaertner, S. (2000). A meta-analysis of antecedents and correlates of employee turnover: Update, moderator tests, and research implications for the next millennium. Journal of Management, 26, 463-488.

Griffeth, R. W., Allen, D. G., \& Barrett, R. (2006). Integration of family-owned business succession with turnover and life cycle models: Development of a successor retention process model. Human Resource Management Review, 16, 490-507.

Griffin, A. E. C., Colella, A., \& Goparaju, S. (2000). Newcomer and organizational socialization tactics: An interactionist perspective. Human Resource Management Review, 10, 453-474.

Haski-Leventhal., \& Bargal, D. (2008). The volunteer stages and transitions model: Organizational socialization of volunteers. Human Relations, 61, 67-102.

Jackson, S. E., Stone, V. K., \& Alvarez, E. B. (1992), Socialization amidst diversity: the impact of demographics on work team oldtimers and newcomers. Research in Organizational Behavior, 15, 45-109.

Jones, G. R. (1983). Psychological orientation and the process of organizational socialization: An interactionist perspective. Academy of Management Review, 8, 464-474.

Jones, G. R. (1986). Socialization tactics, self-efficacy, and newcomers' adjustments to organizations. Academy of Management Journal, 29, 262-279.

Johns, G. (1993). Constraints on the adoption of psychology-based personnel practices: Lessons from organizational innovation. Personnel Psychology, 46, 569-592.

Kammeyer-Mueller, J. D., \& Wanberg, C.R. (2003). Unwrapping the organizational entry process: Disentangling multiple antecedents and their pathways to adjustment. Journal of Applied Psychology. 88. 779-794.

Kickul, J. (2001). Promises made, promises broken: An exploration of employee attraction and retention practices in small businesses. Journal of Small Business Management, 39, 320-335.

Kirchmeyer, C. (1995). Demographic similarity to the work group: A longitudinal study of managers at the early career stage. Journal of Organizational Behavior, 16, 67-83.

Kwesiga, E., \& Bell, P. (2004). Back to organizational socialization: Building a case for the advancement of women in organizations. Equal Opportunities International. 23, 3-20.
Louis, M. R. (1980). Surprise and sense-making: What newcomers experience in entering unfamiliar organizational settings. Administrative Science Quarterly, 25, 226-251.

Louis, M. R., Posner, B. Z., \& Powell, G. N. (1983). The availability and helpfulness of socialization practices. Personnel Psychology, 36, 857-866.

Major, D. A., \& Kozlowski, S. W. J. (1997). Newcomer information seeking: Individual and contextual differences. International Journal of Selection and Assessment, 5, 16-28.

Massey, C. (2005). Entrepreneurship and small business management in New Zealand. Auckland, New Zealand: Pearson Education.

Mayson, S., \& Barrett, R. (2006). The 'science' and 'practice' of HRM in small firms. Human Resource Management Review, 16, 447-455.

Millward, L. J., \& Brewerton, P. M. (2000) Psychological contracts: Employee relations for the twenty-first century? International Review of Industrial and Organizational Psychology, 15, 1 61 .

Mitchell, T. R., Holtom, B. C., Lee, T. W., Sablynski, C. J., \& Erez, M. (2001). Why people stay: Using job embeddedness to predict voluntary turnover. The Academy of Management Journal, 44, 1102-1121.

Morrison, E. W. (1993). Longitudinal study of the effects of information seeking on newcomer socialization. Journal of Applied Psychology, 78, 173-183.

Morrison, E. W. (1995). Information usefulness and acquisition during organizational encounter. Management Communication Quarterly, 9, 131155.

Morrison, E. W. (2002). Newcomers' relationships: The role of social network ties during socialization. Academy of Management Journal, 45, 1149-1160.

Mutjaba, B. G., \& Sims, R. L. (2006). Socializing retail employees in ethical values: The effectiveness of the formal versus informal methods. Journal of Business and Psychology, 21, 261-272.

Ostroff, C., \& Kozlowski, S.W. (1992). Organizational socialization as a learning process: The role of information acquisition. Personnel Psychology, 45, 849-874.

Reichers, A. E. (1987). An interactionist perspective on newcomer socialization rates. The Academy of Management Review, 12, 278-287. 
Rollag, K. (2004). The impact of relative tenure on newcomer socialization dynamics. Journal of Organizational Behavior, 25, 853-872.

Rollag, K. (2007). Defining the term 'new' in new employee research. Journal of Occupational and Organizational Psychology, 80, 63-75.

Rollag, K., Parise, S., \& Cross, R. (2005). Getting new hires up to speed quickly. MIT Sloan Management Review, 46, 35-41.

Saks, A. M. (1994). A psychological process investigation for the effects of recruitment source and organization information on job survival. Journal of Organizational Behavior, 15, 225-244.

Saks, A. M. (2006). Antecedents and consequences of employee engagement. Journal of Managerial Psychology, 21, 600-619.

Saks, A. M., \& Ashforth, B. E. (1997). Organizational socialization: Making sense of the past and present as a prologue for the future. Journal of Vocational Behavior, 51, 234-279.

Saks, A. M., Uggerslev, K. L., \& Fassina, N. E. (2006). Socialization tactics and newcomer adjustment: A meta-analytic review and test of a model. Journal of Vocational Behavior, 70, 413446.

Schein, E. H. (1968). Organizational socialization and the profession of management. Industrial Management Review, 9, 1-16.

Seibert, S. E., Crant, M., \& Kraimer, M. L. (1999). Proactive personality and career success. Journal of Applied Psychology, 84, 416-427.

Sigler, K. J. (1999). Challenges of employee retention. Management Research News, 22, 1-5.

Slattery, J. P., Selvarajan, T. T., \& Anderson, J. E. (2002). Influences of new employee development practices on temporary employee work-related attitudes. Human Resource Development Quarterly, 10, 279-303.
Starr, J. A., \& Fondas, N. (1992). A model of entrepreneurial socialization and organization formation. Entrepreneurship Theory and Practice, 1, 67-76.

Van Maanen, J. (1978). People Processing: Strategies of organizational socialization. Organizational Dynamics, 19-36.

Van Maanen, J., \& Schein, E. H. (1979). Toward a theory of organizational socialization. Research in Organizational Behavior, 1, 209-264.

Wanberg, C. R., \& Kammeyer-Mueller, J. D. (2000). Predictors and outcomes of proactivity in the socialization process. Journal of Applied Psychology, 85, 373-385.

Wanous, J. P. (1992). Organizational Entry: Recruitment, Selection, Orientation, and Socialization. Addison-Wesley, Reading, MA.

Wanous, J. P., Poland, T. D., Premack, S. L., \& Davis, K. S. (1992). The effects of met expectations on newcomer attitudes and behaviors: A review and meta-analysis. Journal of Applied Psychology, 77, 288-297.

\section{Authors}

Robbie Field

Lecturer

Applied Management

Eastern Institute of Technology

Private Bag 1201

Taradale

Napier

Hawke's Bay

RField@eit.ac.nz

\section{Alan Coetzer}

Senior Lecturer

Department of Management

Massey University

P.O. Box 756

Wellington 6140

A.J.Coetzer@massey.ac.nz 